Journal of Nepal Geological Society, 2019, vol. 58 (Sp. Issue), pp. 145-152

DOI: https://doi.org/10.3126/jngs.v58i0.24599

\title{
Nepal, a multi-hazard risk country: Spatio-temporal analysis
}

\author{
*Ganesh Kumar Jimee ${ }^{1}$, Kimiro Meguro ${ }^{2}$, and Amod Mani Dixit ${ }^{3}$ \\ ${ }^{1}$ Institute of Industrial Science, the University of Tokyo and Director, National Society for Earthquake Technology- \\ Nepal (NSET), Kathmandu, Nepal \\ ${ }^{2}$ International Center for Urban Safety Engineering, Institute of Industrial Science, the University of Tokyo, Japan \\ ${ }^{3}$ National Society for Earthquake Technology-Nepal (NSET), Kathmandu, Nepal \\ *Corresponding author: gjimee@nset.org.np
}

\begin{abstract}
Nepal, though covers small area of the earth, exposes complex geology with active tectonic processes, high peaks, sloppy terrain and climatic variation. Combination of such geo-physical and climatic conditions with existing poor socio-economic conditions, unplanned settlements, rapidly increasing population and low level of awareness has put the country in highest risk to multi-hazard events. Fires, floods, landslides and epidemics are the most frequent hazard events, which have cumulatively caused a significant loss of lives and property every year. However, due to diversity in physiographic, climatic and socio-economic conditions within the country, the type, frequency and degree of the impact of such events differs in different places. During the period of 46 years (1971-2016), an average of 2 events have been occurred causing 3 deaths/missing every day. Disaster events occurred most frequently during the months of April, July and August, while relatively lesser number of events have been reported during January, November and December. However, earthquakes have been reported in different months, regardless with the season.
\end{abstract}

This paper is an effort to analyse the spatial distribution and temporal variation of disaster events in Nepal. Further it has drawn a trend of disasters occurrence in Nepal, which will help the decision makers and other stakeholders for formulating Disaster Risk Management (DRM) plan and policies on one hand and heighten citizens' awareness of against disasters on the other.

Keywords: Disaster, Multi-hazard risk, DesInventar, Spatio-temporal analysis

Paper Received: 21 Dec 2018

Paper Accepted: 27 Mar 2019

\section{INTRODUCTION}

Nepal, a Himalayan country, occupies $0.003 \%$ land of the world and $0.03 \%$ of Asia, which is $147,181 \mathrm{sq} . \mathrm{km}$. It is almost rectangle in shape stretching east-west in about 800 kilometres length and 150 to $250 \mathrm{~km}$. north-south width. It has high relief variation starting from 60 meters above the mean sea level to the highest peak on the earth, Mount Everest, and exposure of diverse physiography. Nepal exposes 8 distinct physiographic features namely, Inner and Trans Himalayan Valleys, the Higher Himalaya, the Fore Himalaya, the Mid Lands, the Mahabharat Range, the Dun Valleys, the Siwalik Range and the Southern Terai (Upreti, 2001). Due to such variation in physiography, the country experiences diverse climatic conditions from all-weather snow-covered extreme cold in the north to very hot and moist in the south. Most of the major rivers, originating from glaciers and the Midlands and Mahabharat Range are perineal; and rivers originated from the Siwalik Range are non-perineal (Jimee, et. al., 2008).

According to the 2011 census, the total population of Nepal is 26.5 million with growth rate of 1.35 per annum and median age of 21.6 years. The Central Bureau of Statistics estimates to reach more than 30 million population of the country by 2020 (CBS, 2014). The country has also improved its life expectancy to 69.01 years in 2015 from 66.79 years in 2010 (NPC, 2017). However, the population growth has caused many negative impacts in the human and natural environment such as deforestation and encroachment of open spaces for accommodating the increased population, including many uninhabitable and hazardous areas such as flood plains/river banks, unstable slope areas, swampy areas, inviting disasters.

\section{METHODOLOGY}

This paper has been prepared mainly based on the disaster information collected through DesInventar system maintained by National Society for Earthquake Technology-Nepal (NSET). The system was developed by a team of researchers and academicians of LA RED, the Network of Studies on Disaster Prevention in Latin America in 1990s; and currently more than 30 countries have developed their national disaster databases based on this system (DesInventar, 2018). In this context it is relevant to note that the EM-DAT database maintained by Centre for Research on the Epidemiology of Disasters (CRED) records the disaster events with 1 or more deaths and/or 100 or more people affected/ injured/homeless or declared emergency and/or 
an appeal for international assistance (CRED, 2018). DesInventar is one of the very few methodologies/ tools available, which permits the homogenous capture, analysis and graphic representation of geo-referenced information on disaster occurrence and losses. Realizing the significant cumulative loss due to frequent small and medium level disaster events, Nepal DesInventar system has considered all levels of events reported through media, reports from the government ministries and departments having loss of lives and/or property. Hence, with consensus among the major DRM stakeholders in Nepal in 2003, the database has been recording 29 types of disaster events occurring in Nepal (NSET, 2013). The database considers 10 national and local newspapers, government records/reports, and other event reports collected by the key stakeholders working in the field of DRM such as Department of Water Induced Disaster Management (DWIDM), Nepal Red Cross Society (NRCS) and Nepal Police etc. The current paper has analysed the DesInventar database for the last 46 years (1971-2016).

\section{NEPAL AS A MULTI-HAZARD RISK COUNTRY}

Due to aforementioned physical diversity and climatic variations, Nepal has been frequently facing different types of hazards (MOHA, 2009; Jimee, et al., 2015) such as landslides, fires, epidemics, earthquakes, floods, droughts and glacier lake outburst floods (GLOF), thunderstorms and avalanches, etc., which have been putting people repetitively at risk (MOHA, 2015; MOHA, 2016). In this context, though Nepal lacks the detail disaster information before 1970s, one can imagine and might be right saying 'Nepal has come up with myriad devastating disasters in the past'. The country's location on the astride boundary of two active tectonic plates, diverse physiography and climatic variation are the major causes of hazards (Jimee et al., 2015). Lack of awareness among the people, lack of clear policy and guidelines that are strictly enforced, haphazard urbanization, unplanned development activities, lack of proper land use, encroachment of open areas, deforestation, have turned those hazards to devastating disasters (Jimee et al., 2008, MOHA, 2018). Earthquakes are devastating, and have destroyed the country 5 times even after 19th century i.e. 1934, 1980, 1988, 2011 and 2015. However, many other events, though individually have caused lesser damage in comparison to earthquake, cumulatively they have caused significant loss of lives and property. In this context, DesInvantar has been very useful to keep records of not just large-scale disaster events but also the small and medium scale, and to carry out the analysis for the DRM plans. DesInventar recorded more than 25,800 disaster events causing more than 45,700 deaths/missing and more than 71,000 injuries, more than 800,000 buildings collapsed during the last 46 years (1971-2016). The major disaster events occurred in recent decades are- the floods of 1993 and 2008, earthquakes of 1988 and 2015, landslides of 2013 and 2014, and fires of 1996 and 2008 (NSET, 2016, MOHA, 2015). The database shows that the water induced disasters including debris flow, landslides and floods, etc. are more frequent causing significant loss of lives and property in
Nepal. This has affected negatively the socio-economic and environmental condition of the country (Pradhan, 2013).

\section{SPATIO-TEMPORAL ANALYSIS OF DISASTER EVENTS AND IMPACT}

This paper has tried to analyze the disaster events mainly in two aspects: spatial and temporal. Further, the spatial analysis has been carried out based on the physiographic sections and political regions. Similarly, the temporal analysis includes: longterm (historical) trend and the seasonal variations.

\section{Temporal variation in occurrence of disaster events}

The disaster events recorded since January 1971 to December 2016 through DesInventar database system have been considered for analysis in this paper. During this period of 46 years, total 25,849 disaster events have been reported occurring on average 2 events/day, which have caused on average 3 deaths/missing per day. On average 0.5 events/day occurred during 1971-1990, which was 1.4 events/day during 1991-2000, 2.9 during 2001-2010 and 3 events during 20112016. Similarly, the trend of death/missing also have been increased in the same way i.e. $0.9,1.2,3.4,2.8$ and 6.6 per day during 1971-1980, 1981-1990, 1991-2000, 2001-2010 and 2011 to 2016 respectively. The Fig. 1 also has presented the increasing trend of disaster events. This trend shows that almost in every $4 / 5$ years the rate of disaster events occurrence has been accelerated. The increased number of reported events could be mainly due to 1) the improved disaster event reporting system; 2) coverage and/or access of media; 3 ) increased vulnerability and exposure to hazards with the growing population and urbanization, and also due to multiple reports of the same disaster events, for instance, the 1988 earthquake, 1993 flood and 2015 earthquake have been reported from different affected areas.

Fig. 2 presents the number of deaths/missing due to 15 selected disaster events during the last 46 years. The record shows on average about 1,000 people have been killed and/or missing every year due to disaster events. The greatest number of deaths in a single year 9,442 occurred in 2015 followed by 1,969 in $2001,1,885$ in $1993,1,422$ in $1999,1,398$ in 1997 , 1,279 in 1988 , and so on.

The Gorkha Earthquake in 2015 killed more than 8,800 people. Epidemic and landslide in 2001, flood and landslide in 1993, epidemic and flood in 1999, epidemic and flood in 1997, and earthquake and epidemic in 1988 were the major causing events of deaths/missing during this period. During this period 4 major earthquakes have occurred in 1980, 1988, 2011 and 2015 causing more than 9,700 deaths and/or missing. Earthquakes are not frequent, but once occur, they have caused big loss of lives and property. On the other hand, other disasters such as epidemic, landslide, floods have occurred every year (Fig. 2) and made cumulatively big loss of lives and property though they have not big impact individually as earthquake. 


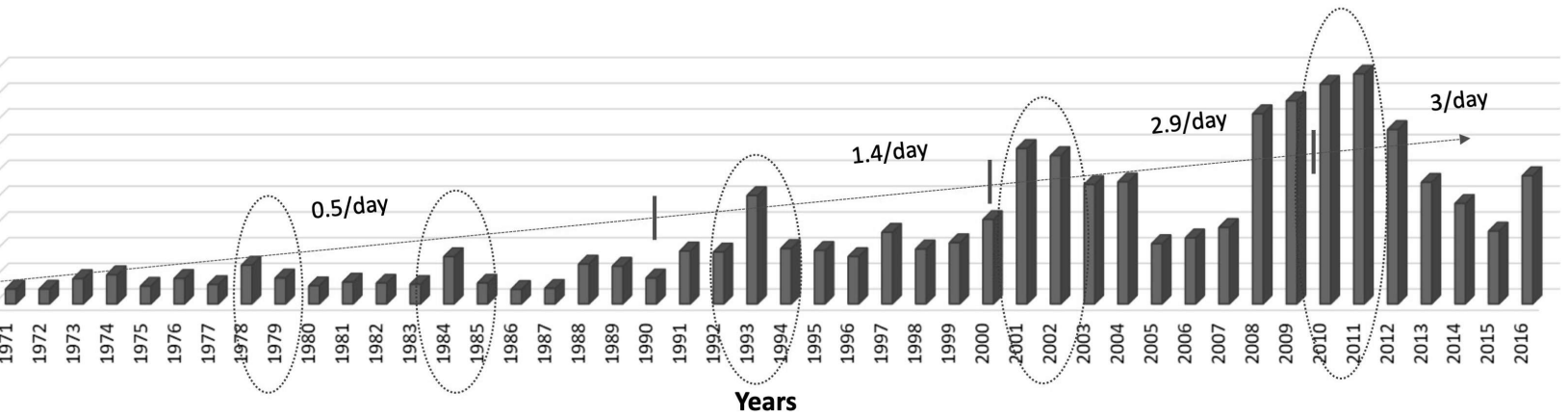

Fig. 1: Reported disaster events in Nepal during last 46 years

(1971-2016) (Source: NSET, DesInventar database, 2018)

Fig. 3 presents the occurrence and impact of disaster events by months. There is no doubt that earthquake has no corelation with the climate and seasonal variation. The history has shown occurrence of earthquake in different months regardless the influence of seasons. However, other disaster events such as the flood, landslide, epidemic, accident and plague have maximum frequency of occurrence during July and August followed by June and September. Nepal experiences rainy season from mid-July to mid-September with extensive rainfall. The floods overtopping river banks in the southern Terai and mid-hills, and landslides on unstable hilly slopes causing loss of lives and property are threatening events during this season. Heavy rain over the sloppy and unstable hills in the north also cause the landslides and flash floods. The most incidents cases of accidents also have been reported during this season. As water-borne diseases like diarrhea, viral hepatitis and typhoid are common during rainy season (WHO, 2018). Epidemics and plagues are reported during July and August.

Nepal suffers from destructive fire (both domestic and forest), strong wind, hail storm and thunder storm in the dry season from March to May followed by February and June. Thus, from the analysis of past 46 years disaster events July, August and April are the months occurring maximum disaster events. More than $47 \%$ of total disaster events, accounting for more than $65 \%$ of total deaths/ missing, have been occurred in these three months. As presented in the Fig. 3, November, December, January and February can be considered relatively safer months from natural disasters. However, as stated above, the earthquakes have no co-relation with seasons.

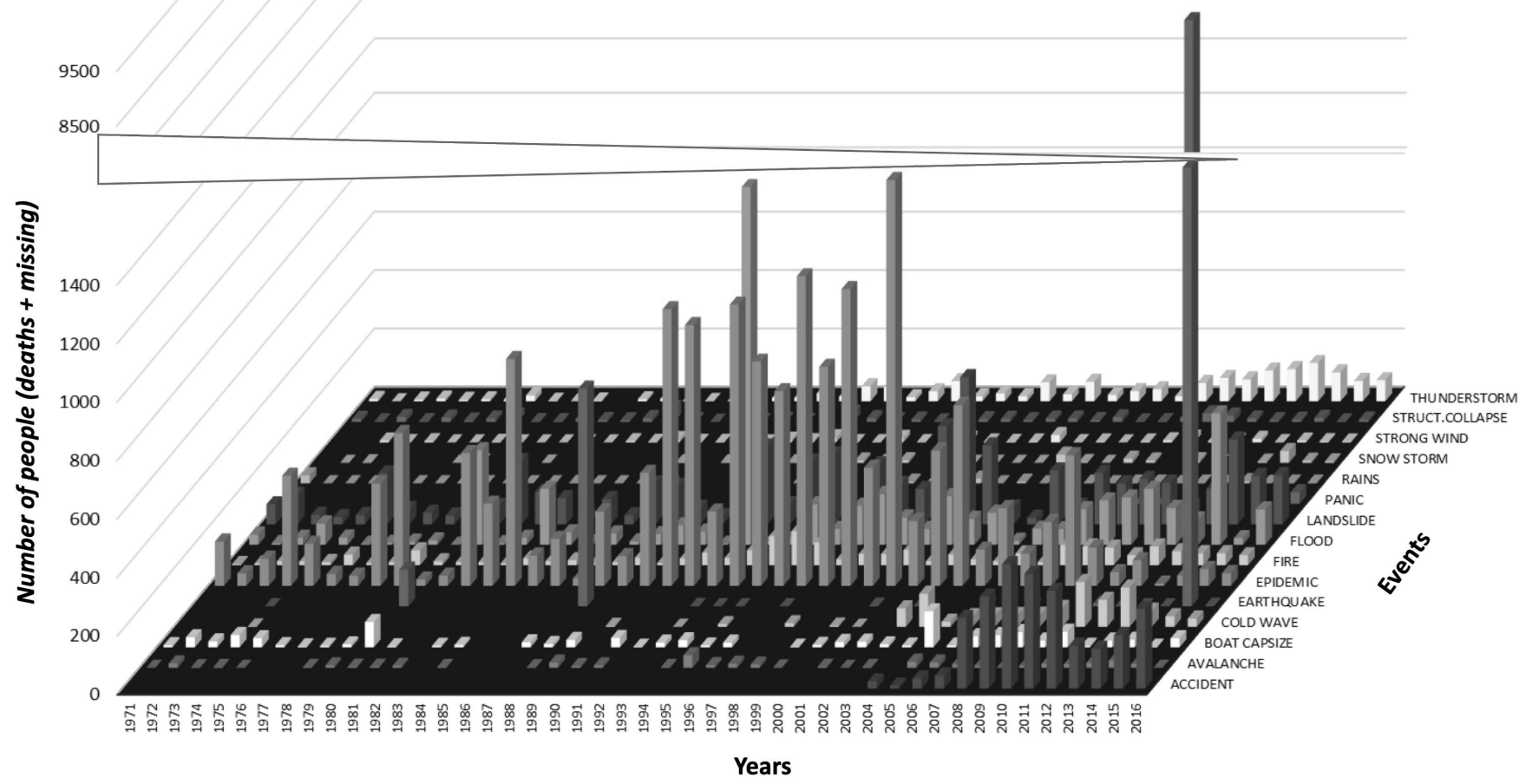

Fig. 2: Death and missing people due to disasters in Nepal during last 46 years (1971-2016) (Source: NSET, DesInventar database, 2018) 


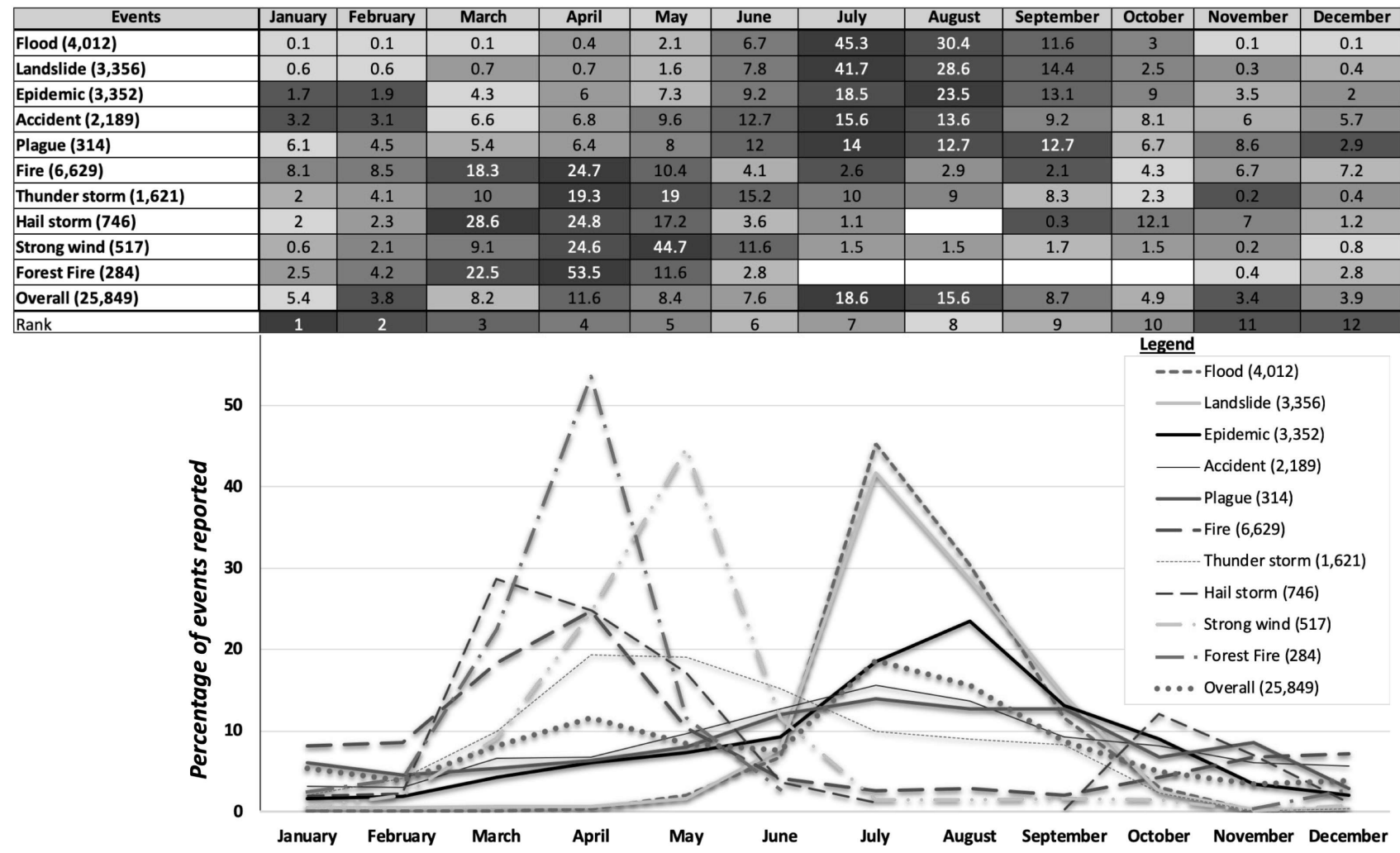

Fig. 3: Frequency of disaster events by different months based on the last 46 years (1971-2016) (Source: NSET, DesInventar database, 2018)

\section{Spatial distribution and impact of the disaster events}

The spatial distribution and impact of disaster events has been mainly analyzed based on geographical and political boundaries in the following sections.

\section{Disaster events by ecological regions}

As Nepal has diverse physiography with high mountains, hills, gorges, plateaus and plains, it experiences variety of climatic conditions at different locations. Thus, the type, frequency and intensity of impact of disaster events vary depending on the physiography and climatic conditions. The highest number of events reported, 53\% is from hilly region followed by $34 \%$ in thr Terai and $13 \%$ from mountain region. However, the proportion of type events differs from one region to other (Figs. 4 and 5), for instance, accident, epidemic, fire, hailstorm, earthquake, plague, heavy rain, storm, structure collapsed, thunder storm are mostly reported from hilly areas followed by the Terai and mountain, respectively. While cold wave, drought, flood, frost, heat wave, strong wind are more frequently reported in the Terai areas followed by hills and mountains. Almost all avalanches and snow storms are reported from mountain areas.

The greatest number of reports of deaths/missing is from hilly areas $(50 \%)$ followed by the Terai $(26 \%)$ and mountain (24\%) areas, respectively. Epidemic, earthquake, landslide, flood, accident, thunderstorm and fire events are the major causes of deaths/missing while maximum buildings have been destroyed by earthquakes, floods, fire and landslides in hilly regions. In the Terai region, epidemic, flood, accident, cold wave, boat-capsize, fire and thunder storm are the major events causing deaths/missing people. Similarly, in mountain region earthquake, epidemic, landslide, flood, accident, avalanche, thunderstorm, fire and snow storm are the major contributing events for deaths/missing people.

\section{Disaster events and their Impact in Chure Region}

The Chure area, situated between main boundary thrust (the southern boundary of the Mahabharat Range) and the main frontal thrust (the northern boundary of the Terai madhesh), spreading over 36 districts partially or complete (GON, 2018) shares $58 \%$ of the total reported disaster events and $39 \%$ of total deaths/missing people. About 4,500 fire events (both domestic and forest fires), more than 3,200 flood events, about 1,300 accidents and more than 900 landslide events have been reported from 36 Chure districts (Fig. 6). While analyzing the death/missing people during these 46 years, epidemic is the major event causing more than $44 \%$ deaths followed by flood (17\%), landslide (7\%), accident (7\%) and earthquake (5\%). More than 3 hundred thousand buildings have been destroyed in the Chure area during this period, $44 \%$ are destroyed by earthquake, $29 \%$ by flood, $23 \%$ by fire, $3 \%$ by landslide and $1 \%$ by strong wind. 


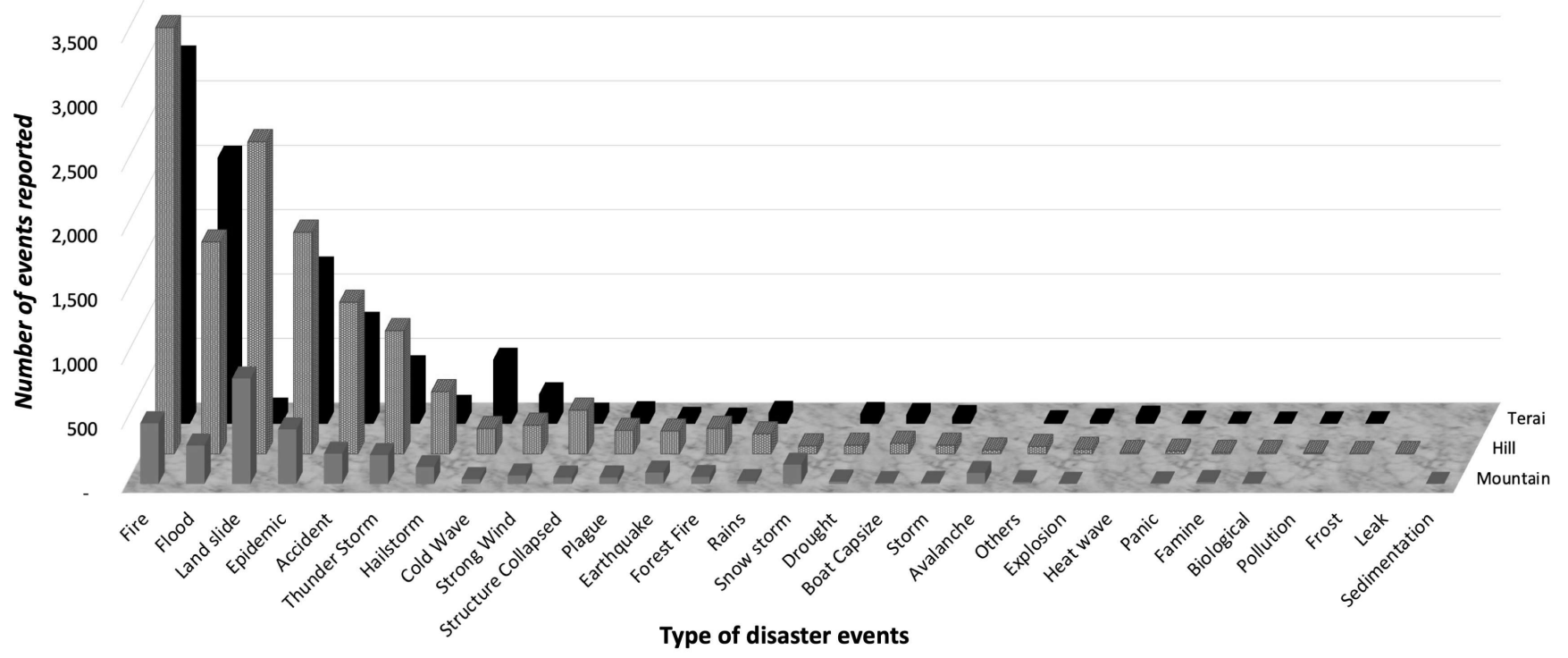

(Source: NSET, DesInventar database, 2018)

Fig. 5: Death and missing people in different ecological regions due to disasters (1971-2016) (Source: NSET, DesInventar database, 2018)

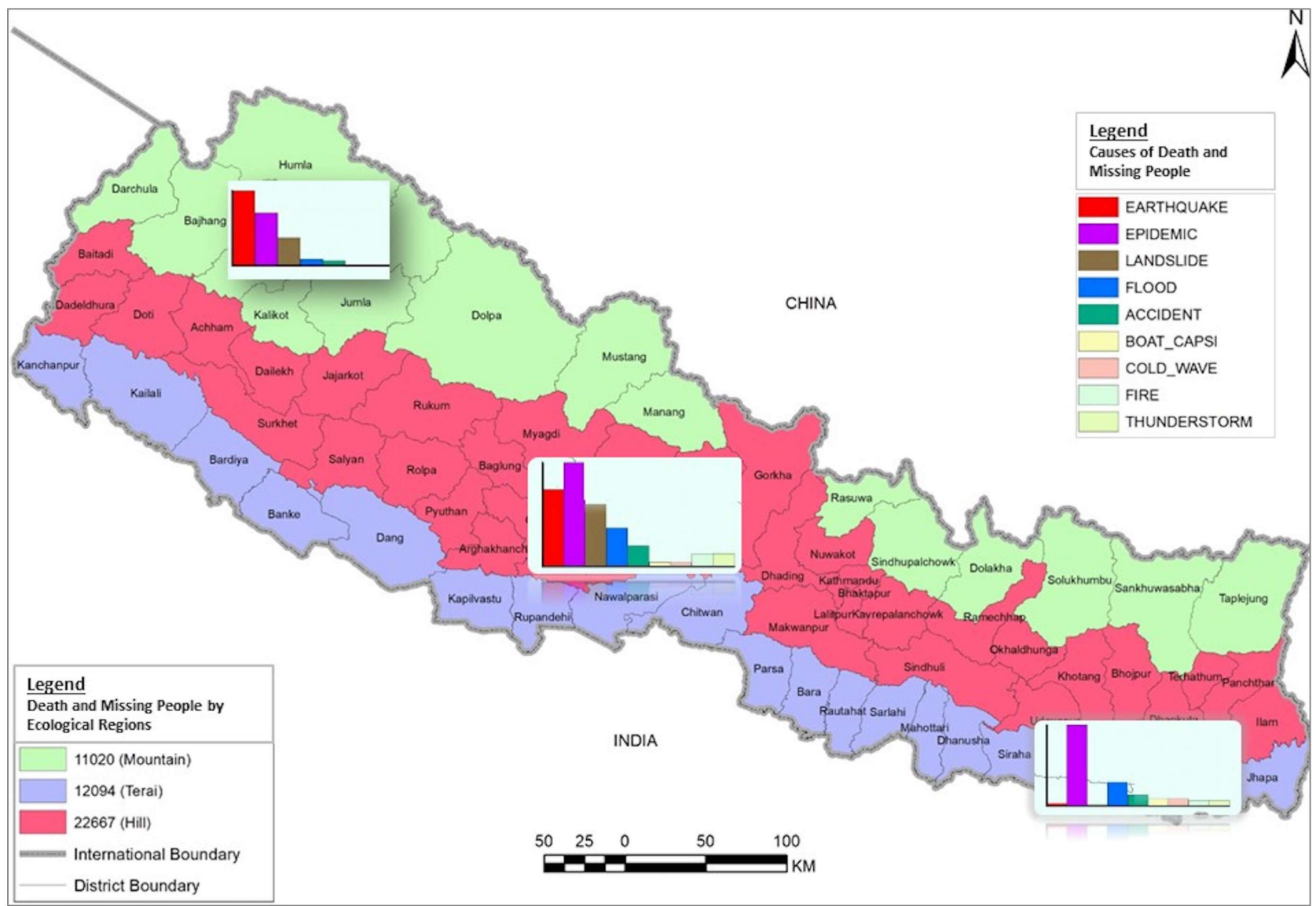

Fig. 6: Occurrence of disaster events and their impact in Chure Region (1971-2016) (Source: NSET, DesInventar database, 2018) 


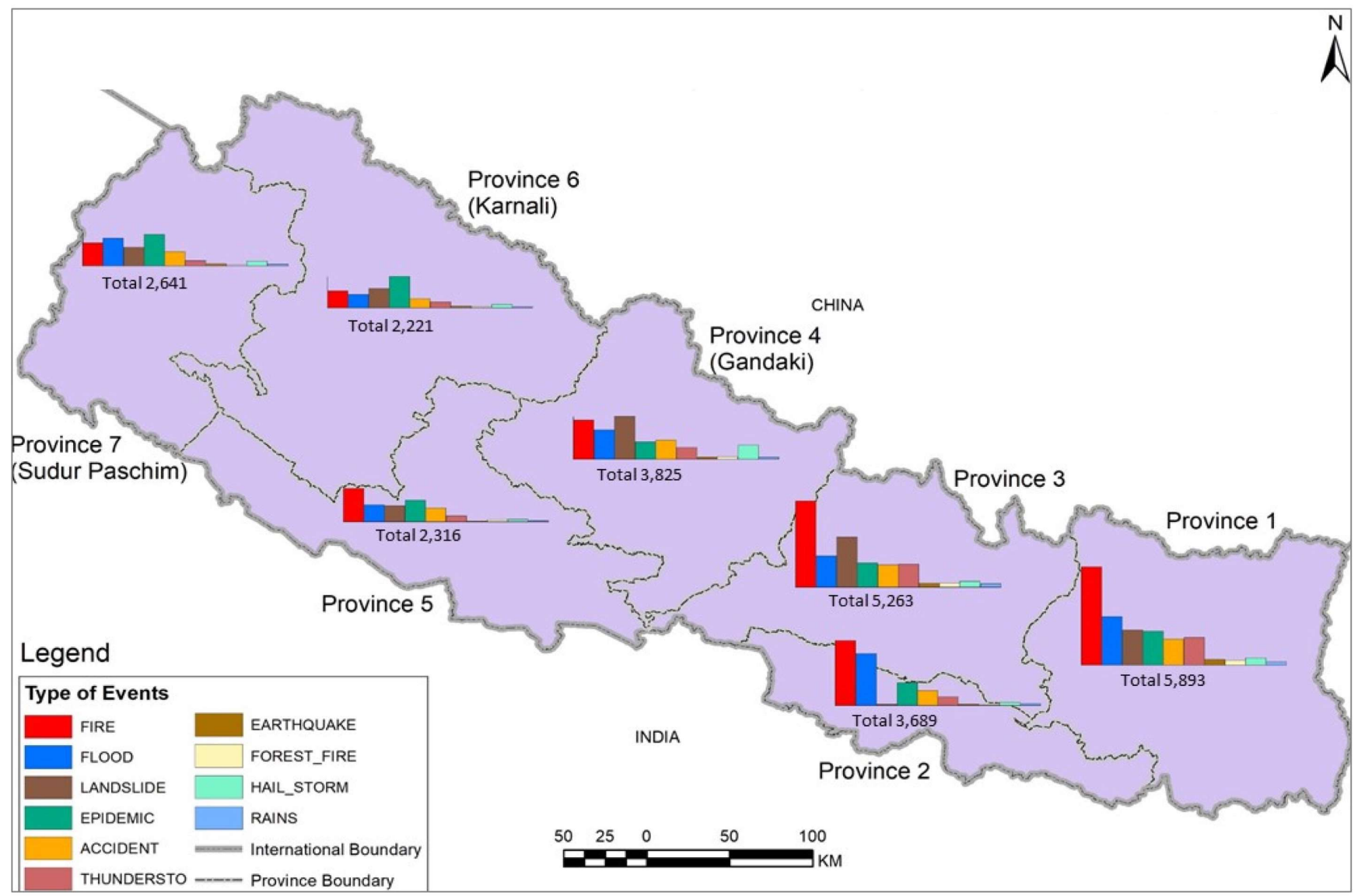

Fig. 7: Types and number of disaster events reported from different provinces of Nepal (1971-2016) (Source: NSET, DesInventar database, 2018)

\section{Disaster events and their impact by Provinces}

Every parts of the country have been affected by one or another type of disaster events. However, the type and extend of disaster impact vary depending on the type of physiography, climate and exposure. Out of total 25,849 reported disaster events, maximum events $(23 \%)$ have been reported from province 1 followed by province 3, 4, 2, 7, 5 and 6 with $20 \%, 15 \%, 14$ $\%, 10 \%, 9 \%$ and $9 \%$ reports respectively. However, $32 \%$ out of total 45,781 deaths/missing have been reported from province 3 followed province 1, 7, 6, 4, 2, and 5 with $14 \% 14 \%, 12 \%$ and $11 \%, 11 \%, 11 \%$ and $9 \%$ deaths/missing people, respectively.

Fig. 7 and Table 1 present the reported disaster events and impact in different provinces during last 46 years. The fire events have been reported most frequently in province 1, 2, 3 and 5 . While landslide is the most frequently reported in province 4 and epidemic from 6 and 7. However, maximum deaths of people are reported due to epidemics from all provinces except in province no. 3 . While in province 3 the large number of deaths/missing are due to earthquake, which is mainly in 2015.

\section{CONCLUSIONS}

Nepal experiences multi-hazard disaster events, the trend of occurrence is increasing every year. In average, 2 events have been occurred every day killing 3 persons during last 46 years (1971-2016). Occurrence of hazards have been highly governed by the physiography and climate, while intensity of impact has been depended on the exposure of elements at risk.

During this period, fire events have been reported most frequently, epidemics have caused maximum deaths and earthquakes have destroyed maximum number of buildings.

Earthquakes, floods, landslides and fire events are individually large in scale, however, other small disasters (e.g. epidemics and accidents, etc.), cumulatively have caused more loss of lives and property. Majority of loss of lives and property in hill and mountainous areas are due to earthquakes, and in the Terai due to floods.

The seasonal variation has been found in occurrence of many disaster events, except earthquake. November, December and January are relatively safer months comparing to others, however, earthquakes have occurred in any months, regardless with the season. 
Nepal, a multi-hazard risk country: Spatio-temporal analysis

Table 1: Reported disaster events and deaths/missing from different provinces of Nepal (1971-2016) (Source: NSET, DesInventar database, 2018)

\begin{tabular}{|c|c|c|c|c|c|c|c|c|c|c|c|c|c|c|c|c|c|}
\hline \multirow{2}{*}{$\mathrm{SN}$} & \multirow{2}{*}{ Disaster Event Types } & \multicolumn{2}{|c|}{ Province 1} & \multicolumn{2}{|c|}{ Province 2} & \multicolumn{2}{|c|}{ Province 3} & \multicolumn{2}{|c|}{ Province 4} & \multicolumn{2}{|c|}{ Province 5} & \multicolumn{2}{|c|}{ Province 6} & \multicolumn{2}{|c|}{ Province 7} & \multicolumn{2}{|c|}{ Nepal } \\
\hline & & $* \mathrm{x}$ & $* * \mathrm{Y}$ & $\mathrm{x}$ & $\mathrm{Y}$ & $\mathrm{x}$ & $\mathrm{Y}$ & $\mathrm{x}$ & $\mathrm{Y}$ & $\mathrm{x}$ & $\mathrm{Y}$ & $\mathrm{x}$ & $\mathrm{Y}$ & $\mathrm{x}$ & $\mathrm{Y}$ & $\mathrm{x}$ & $\mathrm{Y}$ \\
\hline 1 & Epidemic & 624 & 1,779 & 412 & 2,365 & 449 & 1,473 & 318 & 1,283 & 396 & 2,339 & 578 & 3,496 & 576 & 3,563 & 3,353 & 16,298 \\
\hline 2 & Earthquake & 103 & 723 & 15 & 39 & 70 & 8,359 & 36 & 467 & 14 & 4 & 30 & - & 36 & 126 & 304 & 9,718 \\
\hline 3 & Landslide & 642 & 1,182 & 19 & 31 & 920 & 1,928 & 786 & 1,232 & 296 & 558 & 356 & 346 & 337 & 560 & 3,356 & 5,837 \\
\hline 4 & Flood & 889 & 820 & 948 & 1,080 & 574 & 1,053 & 541 & 488 & 309 & 492 & 248 & 500 & 503 & 363 & 4,012 & 4,796 \\
\hline 5 & Accident & 477 & 521 & 270 & 302 & 412 & 498 & 350 & 399 & 251 & 296 & 170 & 197 & 259 & 329 & 2,189 & 2,542 \\
\hline 6 & Thunder storm & 509 & 463 & 156 & 183 & 425 & 414 & 218 & 168 & 109 & 110 & 111 & 97 & 93 & 79 & 1,621 & 1,514 \\
\hline 7 & Fire & 1,800 & 341 & 1,186 & 190 & 1,583 & 349 & 719 & 203 & 612 & 163 & 311 & 105 & 418 & 126 & 6,629 & 1,477 \\
\hline 8 & Cold Wave & 92 & 105 & 345 & 438 & 30 & 45 & 152 & 204 & 48 & 61 & 10 & 22 & 54 & 65 & 731 & 940 \\
\hline 9 & Boat Capsize & 45 & 247 & 17 & 198 & 14 & 31 & 36 & 184 & 16 & 73 & 14 & 41 & 16 & 123 & 158 & 897 \\
\hline 10 & Structural Collapsed & 36 & 50 & 26 & 15 & 226 & 220 & 47 & 36 & 37 & 42 & 39 & 52 & 49 & 33 & 460 & 448 \\
\hline 11 & Avalanche & 34 & 122 & & & 9 & 16 & 46 & 136 & 1 & 1 & 20 & 34 & 4 & 10 & 114 & 319 \\
\hline 12 & Strong Wind & 138 & 73 & 79 & 28 & 71 & 25 & 97 & 16 & 46 & 10 & 29 & 11 & 57 & 29 & 517 & 192 \\
\hline 13 & Snow Storm & 46 & 26 & & & 21 & 7 & 28 & 61 & 6 & 5 & 79 & 46 & 32 & 19 & 212 & 164 \\
\hline 14 & Panic & 11 & 14 & 2 & 2 & 15 & 84 & 3 & 18 & 1 & 1 & 2 & 3 & 2 & 6 & 36 & 128 \\
\hline 15 & Rains & 57 & 18 & 36 & 8 & 67 & 11 & 36 & 21 & 20 & 1 & 22 & 38 & 24 & 3 & 262 & 100 \\
\hline 16 & Forest Fire & 88 & 14 & 10 & 9 & 71 & 28 & 44 & 16 & 31 & 7 & 26 & 23 & 14 & 1 & 284 & 98 \\
\hline 17 & Others & 17 & 16 & 2 & 1 & 14 & 15 & 22 & 17 & 5 & 6 & 10 & 12 & 12 & 9 & 82 & 76 \\
\hline 18 & Hail storm & 130 & 11 & 56 & 4 & 111 & 5 & 257 & 18 & 43 & 5 & 67 & 4 & 82 & 13 & 746 & 60 \\
\hline 19 & Storm & 37 & 22 & 14 & 10 & 21 & 5 & 20 & 2 & 10 & 3 & 3 & - & 22 & 16 & 127 & 58 \\
\hline 20 & Heat Wave & 9 & 10 & 20 & 17 & 2 & - & 5 & 2 & 11 & 8 & 2 & - & 8 & 14 & 57 & 51 \\
\hline 21 & Explosion & 10 & 5 & 10 & 1 & 21 & 13 & 5 & 1 & 5 & 4 & 5 & 7 & 5 & 2 & 61 & 33 \\
\hline 22 & Plague & 38 & 1 & 35 & - & 98 & 3 & 40 & 1 & 26 & 2 & 57 & 11 & 20 & - & 314 & 18 \\
\hline 23 & Famine & 6 & - & 1 & - & 3 & 2 & 1 & - & 1 & - & 11 & 7 & 4 & 1 & 27 & 10 \\
\hline 24 & Frost & 1 & - & 2 & 3 & 2 & - & 1 & 4 & & & & & & & 6 & 7 \\
\hline 25 & Biological & 3 & & 1 & & 6 & & 4 & & 2 & & & & & & 16 & \\
\hline 26 & Drought & 47 & & 27 & & 20 & & 13 & & 19 & & 21 & & 14 & & 161 & \\
\hline 27 & Leak & 1 & & & & 1 & & & & & & & & & & 2 & \\
\hline 28 & Pollution & 3 & & & & 7 & & & & 1 & & & & & & 11 & \\
\hline 29 & Sedimentation & & & & & & & 1 & & & & & & & & 1 & \\
\hline & Total & 5,893 & 6,563 & 3,689 & 4,924 & 5,263 & 14,584 & 3,826 & 4,977 & 2,316 & 4,191 & 2,221 & 5,052 & 2,641 & 5,490 & 25,849 & 45,781 \\
\hline
\end{tabular}

*X Number of Reports; **Y Death and Missing

Proper mechanism for information reporting, collection, recording and analysis at the local

level is very important to develop disaster risk management plans at respective levels.

More than $36 \%$ of total deaths by epidemics, suggest more investment and effective implementation of disease control programs by the Government of Nepal.

More than $76 \%$ of total collapsed buildings caused by earthquake, $11 \%$ by floods and $9 \%$ by fire events, indicates the need of strictly followed earthquake resistant construction practice and effective implementation of Nepal National Building Code.

Spatial analysis of disaster events is crucial for preparing multi-hazard risk sensitive/zoning maps, and temporal analysis is important for developing disaster occurrence calendars.

The multi-hazard risk sensitive land use plan/zoning maps and disaster occurrence calendars are very important for developing disaster risk management strategic plans, counter measures and policy and guidelines at provincial and local governments.

\section{ACKNOWLEDGEMENTS}

The authors acknowledge the Institute of Industrial Science, the University of Tokyo and the National Society for

Earthquake Technology-Nepal (NSET) for providing research opportunity and data information.

\section{REFERENCES}

CRED, the International Disaster Database: Centre for Research on the Epidemiology of Disasters. .

CBS, 2014, National Population and Housing Census 2011: Population Projection 2011-2031, Government of Nepal, National Planning Commission Secretariat.

DesInventar, Inventory System of the Effects of Disasters. Accessed on 2 October 2018.

GON, 2017, President Chure-Terai Madhesh Conservation and Management Master Plan (2074 BS), President ChureTerai Madhesh Conservation Development Board (PCTMCDB), Government of Nepal.

Jimee, G.K., Dixit, A.M., Tandingan, M. T., Sharma, S. 2015, Strategy for Developing Professional Emergency Responders in Nepal. The 14th International Symposium on New Technologies for Urban Safety of Mega Cities in Asia, USMCA2015, October 29-31, 2015, Kathmandu, Nepal

Jimee, G.K., Van Westen, C.J. and Botero, V. 2008, Seismic Vulnerability and Capacity Assessment at Ward Level: A 
Case Study of Ward No. 20, Lalitpur Sub-Metropolitan City, Nepal. The 14th World Conference on Earthquake Engineering, October 12-17, 2008, Beijing, China.

MOHA, 2009, The Hazardscape and Vulnerability. Nepal Disaster Report 2009, Ministry of Home Affairs, Government of Nepal.

MOHA, 2015, Policies, Practices and Lessons. Nepal Disaster Report, Ministry of Home Affairs, the Government of Nepal.

MOHA, 2016, Disaster Risk Reduction in Nepal: Achievements, Challenges and Ways Forward. National Position Paper for Asian Ministerial Conference on Disaster Risk Reduction AMCDRR, 2-5 November 2016, New Delhi, India.

MOHA, 2018, Disaster Risk Reduction and Management in Nepal. National Position Paper for Asian Ministerial Conference on Disaster Risk Reduction (AMCDRR), 36 July 2018, Ulaanbaatar, Mongolia.
NPC, 2017, Demographic Changes of Nepal: Trends and Policy Implications. National Planning Commission, Government of Nepal, Singha Durbar, Kathmandu.

NSET, 2016, DesInventar Database 1971-2016. National Society for Earthquake Technology- Nepal (NSET)

NSET, 2013, Disasters in Nepal: Inventory of Events and Analysis of Impacts 1971-2012, Publication Series No. NSET-077-2013.

Pradhan, L.C., 2013, Assessment of Water Induced DisastersFloods and Land Slides Affected Districts of Nepal by Ranking from 2007/08 to 2012/13. Disaster Review, Series XXI.

Upreti, B.N., 2001, The Physiography and Geology of Nepal and Their Bearing on the Landslide Problem, Landslide Hazard Mitigation in the Hindu Kush-Himalayas. The International Center for Integrated Mountain Development (ICIMOD), Kathmandu, pp. 30-49.

WHO, Regional office for South Asia: An Information Booklet: Seasonal Communicable Disease and Prevention of Antibiotic Resistance/accessed on 4 Nov 2018). 